\title{
An Empirical Analysis of the Relationship between the Managerial Ownership and Corporate Performance in China
}

\author{
Yadan Zhao \\ Department of Information Management \\ Dalian Neusoft University of Information \\ Dongbei University of Finance \& Economics \\ Dalian, China
}

\author{
Haitao Liu \\ Department of Information Management \\ Dalian Neusoft University of Information \\ Dalian, China
}

\begin{abstract}
This study conducts an empirical analysis on the relationship between managerial ownership and corporate performance in China. The objects are 2024 company-year observations from the listed companies traded on Shanghai and Shenzhen Stock Exchanges from 2014 to 2016 after suffering the economic recession in 2008 . Initially, there is a linear relationship with positive coefficient between managerial ownership and corporate performance at low level of ownership in China. Moreover, when controlling the time dummies, an inverted U-Shaped relationship is found, which is consistent with Defense Theory (Chen, 2001). It suggests there is an increase of firm value as the increase of managerial ownership at the low level of ownership but a decrease of firm value as the increase of managerial ownership at the high level of ownership. Furthermore, the firm-fixed effects are added in the model, but most variables turn to be insignificant.
\end{abstract}

Keywords-managerial ownership; corporate performance; inverted $U$-shape; linear relationship

\section{INTRODUCTION}

The influence of managerial ownership on corporate performance has drawn considerable attention from academics and practitioners in recent years; becoming the subject of numerous studies and debates. The reasons for this increased interest are summarised as follows. Initially, according to Demsetz (2001), the management system of ownership has become one of the most important incentive and constraint managements in modern enterprises at moment. Further, the decisions made by those who own shares are strongly reflected by the ownership structure of the firm, then, the corporate performance will be influenced.

In China, under the influence of its special political background, the managerial ownership is defined by some different characteristics. Indeed, China's management equity has been developed alongside the reform of the state-owned enterprise shareholding system. The earliest form of managerial ownership was that of employee shares and it was followed by management equity incentive and

This paper is supported by the research project of "the financial institutions operating model under the Internet plus time" which is belonged to the ministry of education in Liaoning Province China.

Project Number: ZX2015SK014 management buyout. For historical reasons, the equity of listed companies in China is, moreover, divided into tradable shares and non-tradable shares. Under the circumstances, the stock price cannot be seen as a marketbased incentive. The China Securities Regulatory Commission announced 'Measures for the management of the listed company equity incentive' until 2005, which laid the necessary legal basis for China's managerial ownership incentive policy.

This study concentrates on the empirical test on the relationship between managerial ownership and corporate performance. The samples are from the listed companies that traded on the Shanghai and Shenzhen Stock Exchange in China with 2024 company-year observations from 2014 to 2016 .

\section{DATA AND METHODOLOGY}

\section{A. Data}

The research objects are the listed companies traded on Shenzhen and Shanghai Stock Exchanges in China with the three year period from 2014 to 2016. The research data are all obtained from the CSMAR data set (the most authoritative data management system in China).These restrictions yield a final sample of 2024 observations with 704 for 2014, 707 for 2015 and 613 for 2016.

\section{B. Main Hypothesis}

The main hypothesis in the study is H1: There should be a linear relationship between the managerial ownership and the corporate performance.

\section{Corporate mance sure}

To measure performance, we rely mainly on return on assets (ROA) and earnings per share (EPS)

- $\mathrm{ROA}=$ Operating Profit / Book Value of Total assets

- $\mathrm{EPS}=$ Operating Profit / Average Number of Equity

\section{Managerial Ownership}

The managerial ownership in this study is defined as the percentage of the firms' total shares outstanding, equal to 
the number of managerial shares to the total number of equity of the listed company.

$\mathrm{OWN}=$ the number of managerial shares / the total number of equity of listed companies

\section{E. Control Variable}

In this study, control variables were employed to analysis the influence on firm value. The control variables are all have significant influence on the firm's performance, including firm size, leverage ratio (debt rate), and the rate of state held ownership.

$-\mathrm{SIZE}=\log$ of the total assets is natural logarithm of total assets book value at the end of that year. It is measured by total asset, expected to be negatively related to firm performance (Lang and Stulz, 1994)

-Leverage ratio, DEBT Rate $=$ Book value of debt $/$ Book value of assets

-STATE HOLDING RATE= State-owned holding / total number of equity of listed companies model

-INDUSTRY: it is a dummy variable considered in the

-YEAR: it is a dummy variable considered in the model

\section{F. Method of Estimate}

The dataset is an unbalanced panel data in the study. The data employed in this study contain observations of multiple phenomena over 3 year period from 2014 to 2016. Both the cross-sectional data and time series data are included in the sample. Considering the data is longitudinal, so a panel data model is better choice in the study. It is important to contain both the time and firm dummy in the model. Therefore, both the time effects and the firm effects should be analysed in the study, the model is established as follow.

Perit $=\alpha+\beta 1$ OWNit $+\beta 2$ OWNit $2+\beta 3$ SIZEit $+\beta 4$ STATEit $+\beta 4 D E B T i t+\mu 1 D 1 i+\mu 2 D 2 i+\mu 3 D 3 i+\ldots+\mu 827$ $D 827 i+\lambda 1 D 1 t+\lambda 2 D 2 t+\lambda 3 D 3 t+v i t \quad$ Eq.(1)

Where, $\quad i=1,2,3 . . . .827$, and $t=1=2014, t=2=2015, t=3=2016$.

Perit is dependent variable, corporate performance, OWN is the managerial ownership, the number of managerial shares to the total number of equity of listed companies. OWN^ 2 is the squared OWN. Size is Log of the total assets to measure the firm size, state is short for stateowned rate to measure the percents of shares held by the state, Debt is leverage ratio to measure the debt of the firm.

$\alpha$ is a constant leads to potential misspecification due to excluding the unobserved firm heterogeneity

$\beta$ vector of parameters for explantory variables. A positive and significant $\beta 1$ means the firm value will increase or decrease in the same direction with managerial ownership. A negative and significant $\beta 2$ suggesting there is a non-linear relationship between the managerial ownership and corporate performance.

$\mu \mathrm{i}$ is the cross sectional dummy variable coefficient $\lambda \mathrm{x}$ is the time series dummy variable coefficient

vit is the error term

DIi is the cross sectional dummy variable $(=1$ if $\mathrm{N}=\mathrm{I}, 0$ otherwise. For example, "Dli means a dummy variable that takes the value 1 for the observation (the first company) and zero otherwise"(Brooks, 2008, p.491)

Dxt is the time series dummy variable $(=1$ if $T=X, 0$ otherwise.For example, "D1t means a dummy variable that takes the value 1 for the first time period and zero otherwise"

\section{EMPIRICAL ANALYSIS}

This part focuses on the analysis of the empirical results, which are presented in three parts including statistics description, empirical results analysis and robustness tests. Above all, it is mainly to report the relationship between managerial ownership (OWN) and corporate performance (EPS and ROA). Finanly, a positive linear relationship exists consistent with Jensen and Murphy (1990) (supported by Principle-Agent Theory, Team Production Theory and Human Capital Theory) but an inverted U-shape relationship exisits between ROA and OWN when control time dummies consistent with Morck et al.(1988) (supported by Defense Hypothesis).

\section{A. Descriptive Statistics}

This section mainly presents the descriptive statistics for the variables employed in the study and the correlations between the variables.

1) Descriptive Analysis for Managerial Ownership: The data of ownership is generated by the number of managerial shares to the total number of equity of listed companies, which shows the level of the managerial ownership in China. According to the table, it can be seen clearly that the managerial ownership is low but has a rising trend. While the highest managerial ownership happen in year of 2014. The mean of the total sample is $18 \%$. The mean of managerial ownership increases from $16 \%$ in 2014 to $18 \%$ 2016. In this study, the managerial ownership is restricted to the existed stock excluding the options. The managerial ownership is born with the separate of own rights and operation rights in the companies and recognized as an effective mean of management incentive.

TABLE I. DESCRIPTIVE STATISTICS FOR OWN

\begin{tabular}{|r|crrrr|c|}
\hline Year & Observations & Maximum & Minimum & Mean & Var \\
\hline \hline 2014 & 613 & 0.89 & 0.00 & 0.16 & 0.05 \\
2015 & 707 & 0.82 & 0.00 & 0.18 & 0.05 \\
2016 & 704 & 0.82 & 0.00 & 0.18 & 0.05 \\
Tota1 & 2024 & 0.89 & 0.00 & 0.18 & 0.05
\end{tabular}

"Table I" reports the descriptive statistics for own in different years.

2) Descriptive Analysis for Other Variables: This study selected ROA and EPS as the ratio for corporate 
performance. In the meantime, Size, debt and state held ownership rate are the control variables.

TABLE II. DESCRIPTIVE STATISTICS FOR CONTROL VARIABLES

\begin{tabular}{c|cccc} 
Variable & Mean & Std. Dev. & Min & Max \\
\hline roa & 0.0523411 & 0.072469 & -1.170417 & 0.6139638 \\
eps & 0.4870399 & 0.622043 & -2.839178 & 7.582186 \\
own & 0.1752413 & 0.219065 & 0.000000239 & 0.891 \\
own2 & 0.0786753 & 0.1283717 & $5.69 \mathrm{E}-14$ & 0.793881 \\
size & 21.55785 & 1.187957 & 15.72943 & 26.66028 \\
debt & 0.4126053 & 0.9473522 & 0.0123337 & 29.49299 \\
state & 0.0460345 & 0.1248016 & 0 & 0.8619848
\end{tabular}

In " Table II", ROA and EPS, they both are the ratios to show the corporate performance but in different view. ROA is the return on assets while EPS is the earn per share (Combs et. al. 2007). The means of ROA and EPS are 0.05 and 0.48 respectively, it means the sample companies have profitability.

The OWN had been explained, here mainly to highlight the variable of $\mathrm{OWN}^{\wedge} 2$. According to the previous studies discussed in the literature review part, the relationship between managerial ownership and corporate performance exist the non-linear relationship besides the linear relation. Hence, the variable of OWN is to test the linear relationship and $\mathrm{OWN}^{\wedge} 2$ is to test the non-linear relationship. According to the correlation test in Stata, both OWN and OWN^2 has the p-value less than 5\%, hence the null hypothesis should be rejected.

The variables of size, debt and state owned rate are all control variables to enhance the finding of the study. Hence the mean of 21.55 is a $\log$ value. According to the table above, only $4 \%$ shares are owned by the state on average that is quite less than management. However, it is larger than that compared with the rate in other countries. All in all, the governments in China control most of the social sources. As all the p-value of correlation test is less than 5\%, they are significant.

\section{3) Pearson Correlation Analysis}

It products a Pearson Correlation analysis as following "Table III".

The variables selected in this study show a significant correlation with corporate performance suggesting the variables in the study is effective and do affect the corporate performance. Generally, OWN, OWN^2, firm size and state owned rate all carry a positive sign to the EPS and ROA while Debt carries a negative sign. The state owned rate is not correlated with ROA.

According to the table of Pearson correlation, managerial ownership (OWN) and squared-OWN (OWN^2) is positive and significant related with ROA and EPS at level of $1 \%$ and $3 \%$. This is should be the basic for the relationship analysis. However, from this table, it is impossible to know the specific information of the relationship, such as linear relationship or non-linear relationship. Regarding the details of the relationship will be discussed in the empirical test section. In the meantime, the control variables SIZE are significantly correlated with ROA and EPS with a positive sign. As for the variable DEBT, it carries a negative sign for ROA and EPS at the significant level of $1 \%$. State owned rate is positive with EPS at the significant level of $1 \%$. But it shows insignificant relation with ROA, the reason to meet this problem is the calculation for state owned rate is based on the amount of shares so the EPS is more accuracy than ROA to measure State owned rate.

\section{TABLE III. RESULTS FOR PEARSON TESTS}

\begin{tabular}{|c|c|c|c|c|c|c|c|}
\hline & roa & eps & own & own 2 & size & debt & state \\
\hline roa & 1 & & & & & & \\
\hline \multirow[t]{2}{*}{ eps } & p. $6674 * * *$ & 1 & & & & & \\
\hline & 0 & & & & & & \\
\hline \multirow[t]{2}{*}{ own } & p. 0993*** & $0.0483 * *$ & 1 & & & & \\
\hline & 0 & 0.0299 & & & & & \\
\hline \multirow[t]{2}{*}{ own 2} & p. $0862 * * * 0$ & 0. $0548 . * * 0$ & $9586 * * *$ & 1 & & & \\
\hline & 0.0001 & 0.0137 & 0 & & & & \\
\hline \multirow[t]{2}{*}{ size } & p. 0545. ** & 0. $2636 * * * 0$ & 3376. $* * 0$. & $2856 . * *$ & 1 & & \\
\hline & 0.0142 & 0 & 0 & 0 & & & \\
\hline \multirow[t]{2}{*}{ debt } & p. 2524. **10 & 0. $0678 . * * 0$ & 1319. $* * 0$. & $1146 . * *$ & 0.0271 & 1 & \\
\hline & 0 & 0.0023 & 0 & 0 & 0.2224 & & \\
\hline state & -0.00490 & 0. $0625 * * * 0$ & 2336. **0. & 1997. **0 & $2023 * * *$ & 0.0175 & 1 \\
\hline
\end{tabular}

\section{B. Regression Analysis}

Stata12 is used to conduct the regression; this section starts with a multivariate analysis for the relationship between managerial ownership and EPS/ROA. The analysis about EPS and ROA will be presented separately. The results of the multivariate analysis are reported in "Table 9" and "Table 10". The analysis of the 2024 company-year pooled data are based on the Eq.(1) with constant $\alpha$ across companies. The explanatory variables for the regression are identical to those explained in the last section. The data in the study are obtained from the annual reports of the listed companies in China and CSMAR database. The analysis is conducted for the whole sample period, 2014-2016.

There are two notes for the regressions. Firstly, for fixed effects test in Stata, the commands for $\mathrm{n}$ entity-specific intercepts and common intercept with n-1 binary regressions provide the same results. So, the table below is a combination summary of the results. Secondly, to be noted all the regression tests in Stata employ the option of "robust" to control for heteroskedasticity. According to Bruderl (2005), when the time period is short, it is no problem for unobserved heterogeneity. In this study the 3 year time period from 2014 to 2016 is short enough, therefore, the heterogeneity is unobserved for the whole test.

1) EPS VS Managerial Ownership: A multivariate analysis for EPS and ownership has been reported as below. In general, a positive linear relationship exists between managerial ownership and EPS which is consistent with 
Principle-agent Theory, Human Capital Theory and Team Production Theory.

In Model 1, OWN is the only independent variable included to test the effects on firm value. According to "Table IV", the null hypothesis that the coefficient of OWN is zero is rejected at the $1 \%$ significance level for the full sample. And a positive relationship between managerial ownership and the EPS is found in this model, means that the EPS changes in the same direction with managerial ownership.

TABLE IV. RESULTS OF THE DETERMINANTS OF EPS

\begin{tabular}{|c|c|c|c|c|c|}
\hline & Model1 & Model2 & Model3 & Model4 & Model5 \\
\hline _cons & $\begin{array}{l}0.447^{n+\cdots+1} \\
(18.68)\end{array}$ & $\begin{array}{l}0.457^{n+\cdots+n} \\
(18.01)\end{array}$ & $\begin{array}{c}-2.332^{n+m} \\
(-6.86)\end{array}$ & $\begin{array}{c}-2.317^{m} \\
(-6.78)\end{array}$ & $\begin{array}{c}-3.166^{n+m / n} \\
(-9.19)\end{array}$ \\
\hline own & $\begin{array}{l}0.212^{m+m} \\
(2.65)\end{array}$ & $\begin{array}{c}-0.0886 \\
(-0.33)\end{array}$ & $\begin{array}{c}0.428^{m * n+m} \\
(5.29)\end{array}$ & $\begin{array}{l}0.324 \\
(1.24)\end{array}$ & $\begin{array}{l}0.712^{m+*} \\
(2.76)\end{array}$ \\
\hline $\operatorname{own}^{\wedge} 2$ & & $\begin{array}{l}0.535 \\
(1.18)\end{array}$ & & $\begin{array}{l}0.183 \\
(0.42)\end{array}$ & $\begin{array}{l}-0.506 \\
(-1.17)\end{array}$ \\
\hline size & & & $\begin{array}{c}0.127^{*+* n} \\
(8.13)\end{array}$ & $\begin{array}{c}0.126^{*+*} \\
(8.07)\end{array}$ & $\begin{array}{l}0.171^{n+m} \\
(10.77)\end{array}$ \\
\hline debt & & & $\begin{array}{c}-0.0206 * \\
(-2.06)\end{array}$ & $\begin{array}{c}-0.0206^{*} \\
(-2.06)\end{array}$ & $\begin{array}{c}-0.0252^{m+*} \\
(-2.66)\end{array}$ \\
\hline state & & & $\begin{array}{c}0.376^{n+m * n} \\
(3.29)\end{array}$ & $\begin{array}{l}0.374^{* * *} \\
(3.28)\end{array}$ & $\begin{array}{l}0.176 \\
(1.57)\end{array}$ \\
\hline $\begin{array}{l}\text { Dummy } \\
\text { (Year) }\end{array}$ & & & & & YES \\
\hline $\begin{array}{l}\text { R2 } \\
\text { WALD }\end{array}$ & $\begin{array}{c}0.0023 \\
7.03 * * *\end{array}$ & $\begin{array}{c}0.0031 \\
8.42 * * *\end{array}$ & $\begin{array}{c}0.0918 \\
95.06 * * * *\end{array}$ & $\begin{array}{c}0.0913 \\
95.18 * * * *\end{array}$ & $\begin{array}{c}0.1123 \\
258.82 * * *\end{array}$ \\
\hline $\begin{array}{l}\text { Chi } \\
\text { Prob > } \\
\text { chi }\end{array}$ & (0.01) & (0.01) & $(0.00)$ & (O.OO) & (0.00) \\
\hline $\mathbf{N}$ & 2024 & 2024 & 2024 & 2024 & 2024 \\
\hline
\end{tabular}

In Model 2, both $\mathrm{OWN}$ and $\mathrm{OWN}^{\wedge} 2$ are included to test whether there is a possible curvilinear relationship exists. It can be seen that the coefficient is negative for OWN and positive for $\mathrm{OWN}^{\wedge} 2$, but neither the OWN nor $\mathrm{OWN}^{\wedge} 2$ is statistically significant at $10 \%$ level. In conclusion, neither a linear relation nor a curvilinear interest-alignment effect can be found for EPS.

In model 3, the other control variables which effecting EPS are included to the model additionally. Firstly, OWN is positive correlated with firm value and is significant at the $1 \%$ level. Secondly, Size and State Rate had the same effect as OWN, positive relation with EPS at the $1 \%$ level. Thirdly, Debt had a negative relationship with EPS and it is significant at the level of $5 \%$. Overall, the model 3 is significant, although the adjust $\mathrm{R}^{\wedge} 2$ is $9 \%$ might caused by the sample limitation. It suggests that the EPS changes in the same direction with managerial ownership and there is linear relationship between corporate performance and managerial ownership at low levels of ownership.

Then, investigating the effects of the other variables, the coefficient of Size "log (total assets)" is positive suggesting a larger and more diversified company will lead to an increase in the firm value. Due to China's rapid economic development during the year from 2014 to 2016 after the economic recession. The Debt (total debt to total asset) is significantly negative related with firm value according to the data in Japan. It is reasonable to show that the more debt in the companies will delay the development of the companies. But the level of debt should be kept in appropriate rate as the debt can be used as a means to encourage managerial operate companies and it provides an opportunity to do the investments. The State owned rate is a positive and significant sign meaning the EPS increase when the State ownership increases. This result is similar with the previous study in China. The state ownership in China is an important and positive to the company performance considering the government control the most sources in China. Hence, the more state owned shares leads to higher EPS in China.

In Model 4, the study test the relationship with OWN, $\mathrm{OWN}^{\wedge} 2$ and other control variables, SIZE Debt and State Rate together. It can be seen from the results, the OWN, $\mathrm{OWN}^{\wedge} 2$, SIZE and STATE Rate are all positive with the EPS, but $\mathrm{OWN}$ and $\mathrm{OWN}^{\wedge} 2$ are insignificant at $10 \%$ level while SIZE and STATE Rate are significant at $1 \%$ level. As for Debt, it is negative with EPS and significant at the level of $5 \%$. In conclusion, the model is significant but shows insignificant relationship between $\mathrm{OWN}, \mathrm{OWN}^{\wedge} 2$ and EPS.

Model 5 is a promotion upon model 4 in specifications except that it includes yearly dummy variables. As the structural changes over time might exist in the pool data, it is important to include the yearly dummy variables in the analysis. The existence of cross-sectional variations and time-series variations are all allowed in the structural relationship.

In Model 5, time dummies (the three year 2014, 2015 and 2016), managerial ownership (OWN), squared managerial ownership $\left(\mathrm{OWN}^{\wedge} 2\right)$ and control variables tested in Model 4 are all considered. After the regression, OWN is significantly positive correlated with firm value but $\mathrm{OWN}^{\wedge} 2$ is insignificant and negative with firm value. It can be seen as there is a linear relationship exists between managerial ownership and EPS. It is worth noting that the yearly dummy variables 2015 and 2016 are both significant and negative. In regard with $\mathrm{R}^{\wedge} 2$, the time dummies and control variable contribute about $10 \%$ considering the $\mathrm{R}^{\wedge} 2$ in Model 5 and Model 1. Above all, it is a positive linear relationship as well.

\section{2) ROA VS Managerial Ownership}

Because ROA is also an important index to measure corporate performance in China, this study will conduct the similar regressions for ROA as well. Finally, the results presents that there is a linear relationship between managerial ownership and corporate performance but there is an inverted U-shape relation when control the time dummies. The inverted U-shape relationship was found by Morck et al. (1988) which were consistent with Defense Theory as there should be an optimal level for the managerial ownership.

In "Table V", this study reports regression results of the same models as that presented in "Table IV", except change the dependant variable from EPS to ROA. 
TABLE V. RESUlts OF THE DETERMINANTS OF ROA

\begin{tabular}{|c|c|c|c|c|c|}
\hline & Model1 & Model2 & Model3 & Model4 & Model5 \\
\hline $\begin{array}{l}\text { cons } \\
\end{array}$ & 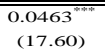 & 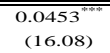 & $\begin{array}{c}-0.0541 \\
(-1.41)\end{array}$ & $\begin{array}{c}-0.0606 \\
(-1.56)\end{array}$ & $\begin{array}{c}-0.0871 " \\
(-2.22)\end{array}$ \\
\hline own & $\begin{array}{l}0.0341^{m .3 n+m} \\
(3.72)\end{array}$ & $\begin{array}{c}0.0643^{* \prime} \\
(2.04)\end{array}$ & $\begin{array}{c}0.0380^{m+n+m} \\
(4.04)\end{array}$ & $\begin{array}{c}0.0758^{* \prime} \\
(2.43)\end{array}$ & $\begin{array}{c}0.0911^{* * * *} \\
(2.91)\end{array}$ \\
\hline own^2 & & $\begin{array}{c}-0.0538 \\
(-1.00)\end{array}$ & & $\begin{array}{c}-0.0662 \\
(-1.27)\end{array}$ & $\begin{array}{c}-0.0981^{\prime \prime} \\
(-1.75)\end{array}$ \\
\hline size & & & $\begin{array}{c}0.00483^{* *} \\
(2.74)\end{array}$ & $\begin{array}{c}0.00507^{*+*} \\
(2.86)\end{array}$ & $\begin{array}{c}0.00656 \\
(3.65)\end{array}$ \\
\hline debt & & & $\begin{array}{c}-0.0134^{m+n+1} \\
(-9.16)\end{array}$ & $\begin{array}{c}-0.0134^{\text {nat. }} \\
(-9.13)\end{array}$ & $\begin{array}{c}-0.0135^{n+\cdots+\infty} \\
(-9.28)\end{array}$ \\
\hline state & & & $\begin{array}{l}0.0233 \\
(1.62)\end{array}$ & $\begin{array}{c}0.0242 \\
(1.68)\end{array}$ & $\begin{array}{l}0.0174 \\
(1.20)\end{array}$ \\
\hline $\begin{array}{l}\text { Dummy } \\
\text { (Year) }\end{array}$ & & & & & YES \\
\hline $\mathbf{R 2}$ & o. 0099 & 0.0108 & 0.0727 & 0.0741 & 0.0792 \\
\hline WALD chi & 13.82 **** & $14.84 * * * *$ & 109.96 **** & 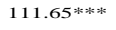 & $139.76^{* * * * * * * 1}$ \\
\hline $\begin{array}{l}\text { Prob > chi } \\
\boldsymbol{N}\end{array}$ & $\begin{array}{l}(0.00) \\
2024\end{array}$ & $\begin{array}{l}(0.00) \\
2024\end{array}$ & $\begin{array}{l}(0.00) \\
2024\end{array}$ & $\begin{array}{l}(0.00) \\
2024\end{array}$ & $\begin{array}{l}(0.00) \\
2024\end{array}$ \\
\hline
\end{tabular}

According to the information shown, the OWN carries a positive sign for the ROA at statistic significant in the five models. It reports the same result with EPS. Hence, the managerial ownership increase will lead to an increase of firm value.

For the $\mathrm{OWN}^{\wedge} 2$ to test the high level of managerial ownership, it carries a negative sign for ROA. To note here, different from the test for EPS, the $\mathrm{OWN}^{\wedge} 2$ is significant at the level of $10 \%$ in model 5 when controlling yearly dummy. It suggests a curvilinear interest-alignment effect. However, in model 5, the coefficients are positive on OWN and negative on $\mathrm{OWN}^{\wedge} 2$. It is an inverted $\mathrm{U}$ shape for relationship between the corporate performance and managerial ownership. The ROA increases as managerial ownership increase when the ownership level is low but ROA decreases as managerial ownership increase when the ownership is high. This result is the same with findings using US data but not consistent with Japan data.

As for the SIZE and State owned rate play the same influence for ROA as that for EPS. They both carry positive sign for corporate performance. But, State owned rate is not as significant as it for EPS. The variable DEBT is significant with negative sign, which is consistent with that for EPS.

To conclude, a mixed result can be found in the OLS regression for ROA. Initially, an invert U-shape relation can be found in model 5 if the SIZE, DEBT, STATE and the time dummies is controlled. In the meantime, the SIZE and DEBT are both significant with positive and negative influence to ROA respectively. Further, when control the variables but not include the time dummies, a positive linear relationship suggests that firm value increases if the managerial ownership increases.

\section{CONCLUSION}

Combine the analysis for the regressions of EPS and ROA together, the corporate performance is significant and positive related with managerial ownership but an inverted U-shape relation exists when time dummy is controlled.
According to the analysis of the models, it offers a few possible explanations as below.

\section{A. EPS VS ROA.}

Managerial ownership has a positive linear relationship with EPS rather than a curvilinear relationship which is consistent with Mehran (1995) and Himmelberg et al. (1999) , which is supported by Human Capital Theory, Principle-agent Theory and Team Production Theory. But an inverted U-shaped relationship is found between ROA and managerial performance which is consistent with Defense Theory and the US data investigated by Morck et al. (1988). At low ownership, the more shares owned by the management will incentive the managers to work hard on the corporate operation to gain a high ROA and EPS. But at the high ownership, the increase of managerial ownership will lead to a decrease of ROA and increase of EPS.

\section{B. DEBT Financing VS Equity Financing}

The coefficient of debt rate is negative with the corporate performance at the significant level of $5 \%$. It shows the pecking-order theory is not suitable to China. In China, the order for corporate financing is equity financing first and then debt financing. Especially for the listed companies, few companies will give up the opportunity of equity financing to conduct debt financing.

\section{Low Managerial Ownership VS High Managerial Ownership}

The managerial ownership level is very low in China according to the description in the last section. The mean of managerial ownership in China is $18 \%$. So the phenomenon of the more ownership held by the management will lead to a negative affect argued by Fama and Jensen (1983), but considering the low rate of managerial ownership in China, the negative affect is not as serious as it presented.

\section{ACKNOWLEDGMENT}

I would like to express my great appreciation to my supervisor, Dr. Minghui.Liu. The assistance provide by her, not only her valuable suggestions and comments on my research work, but also her patient guidance, enthusiastic encouragement and useful critiques are extremely helpful on my work.

\section{REFERENCES}

[1] Brooks, C, Introductory Econometrics for Finance, Cambridge: Cambridge University Press, 2008, pp.68-73

[2] Duchin, R, Matsusaka, J, and Ozbas, O, 'When are outside directors effective?', Journal of Financial Economics, 2010, Vol. 96, p195-214.

[3] Fama E.F. Agency problems and the theory of the firm. Journal of Political Economy, 1980, 88, 288-325

[4] Griffith, J.M. CEO Ownership and Firm Value[J], Managerial and Decision Economics, 1999, (120):1-8.

[5] Kaplan, S.N., Top executive rewards and firm performance: A comparison of Japan and the United States. Journal of Political Economy, 1994, 102, 510-546.

[6] Kiel, G. and Nicholson, G, 'Can Directors Impact Performance? A case-based test of three theories of corporate governance', Corporate Governance: An International Review, 2007, Vol. 15, p585-608 
[7] Jensen, M., Meckling, W., Theory of the firm: managerial behavior, agency costs, and ownership structure. Journal of Financial Economics 1976, 3, 305-360.

[8] Lefort, F, and Urzua, F, 'Board independence, firm performance and ownership concentration: Evidence from Chile', Journal of Business Research, 2008, Vol. 61, p615-622

[9] Zhou, X.M. Understanding the determinants of managerial ownership and the link between ownership and performance: Comment $[\mathrm{J}]$ Journal of Financial Economics, 2001, (62): 559-571 